\title{
Metabotropic Glutamate Receptor mRNA Expression in the Basal Ganglia of the Rat
}

\author{
Claudia M. Testa, ${ }^{1,2}$ David G. Standaert, ${ }^{1}$ Anne B. Young, ${ }^{1}$ and John B. Penney Jr. ${ }^{1}$ \\ 'Department of Neurology, Massachusetts General Hospital, and Harvard Medical School, Boston, Massachusetts 02114 \\ and ${ }^{2}$ Neuroscience Program, University of Michigan, Ann Arbor, Michigan 48109
}

\begin{abstract}
Metabotropic glutamate receptors (mGluRs) couple the actions of glutamate to intracellular second messenger systems through G-proteins. The mGluRs play an important role in the regulation of basal ganglia function. Ligand binding studies have revealed that the basal ganglia contain at least two pharmacological types of metabotropic binding sites. Agonists of mGluRs can affect both in vitro electrophysiologic responses of striatal neurons and motor behavior in vivo. Recently, cDNAs encoding five mGluRs have been cloned, each with distinct structural and pharmacological properties. In order to elucidate the function of these receptors in the biology of the extrapyramidal motor system, we have used in situ hybridization to examine the regional and cellular expression patterns of mGluR1-mGluR5 in the adult rat basal ganglia. In the striatum, all of these mGluRs were present in widely varying relative densities and cellular patterns. MGluR5 was particularly prominent, and exhibited a heterogeneous cellular distribution, with labeled and unlabeled populations of neurons. MGluR2 was expressed in a small population of large polygonal striatal neurons. The subthalamic nucleus was the only other basal ganglia structure that expressed mGluR2. Distinct cellular distributions of mGluR expression were also observed within the nucleus accumbens, globus pallidus, ventral pallidum, and substantia nigra pars reticulata. MGluR3 was expressed in glia in all basal ganglia structures, but was observed in neurons only in the striatum, substantia nigra pars reticulata, and very weakly in the subthalamic nucleus. Comparison of the restricted mGluR2 and mGluR3 mRNA distributions with that of metabotropic ligand binding sites supports a possible presynaptic location for these receptors in the basal ganglia. MGluR1 was the only mGluR message prominently expressed in the dopaminergic neurons of the substantia nigra pars compacta, suggesting the involvement of this receptor in the regulation of dopamine release from nigrostriatal terminals.

[Key words: basal ganglia, metabotropic glutamate receptor, in situ hybridization, striatum, subthalamic nucleus, glutamateJ
\end{abstract}

\footnotetext{
Received July 15, 1993; revised Oct. 14, 1993; accepted Oct. 26, 1993.

We thank $Z$. Hollingsworth for excellent technical assistance. This work was supported by U.S. Public Health Service Grants NS19613 and AG08671. D.G.S. is a Howard Hughes Medical Institute Physician Research Fellow and a recipient of an American Academy of Neurology Research Fellowship Award in Neuropharmacology. C.M.T. is a member of the Medical Scientist Training Program of the University of Michigan.

Correspondence should be addressed to John B. Penney, Jr., M.D., Department of Neurology, Warren 408, Massachusetts General Hospital, Fruit Street, Boston, MA 02114.

Copyright (C) 1994 Society for Neuroscience $0270-6474 / 94 / 143005-14 \$ 05.00 / 0$
}

The basal ganglia are a group of deep forebrain nuclei that play an important role in the regulation of motor behaviors and are central to the pathophysiology of many common human movement disorders, including Parkinson's disease and Huntington's disease. Glutamate is the major excitatory neurotransmitter of both afferents to the basal ganglia and connections between basal ganglia nuclei. The corticostriatal pathway is the largest, most extensively studied of the basal ganglia glutamatergic pathways (Kim et al., 1977; McGeer et al., 1977; Young et al., 1981), although both the subthalamic nucleus (STN) and substantia nigra also receive excitatory glutamatergic cortical afferents (Beckstead, 1979; Lee et al., 1988; Canteras et al., 1990; Groenewegen and Berendse, 1990). Within the basal ganglia, the projections of the STN to the substantia nigra, pallidum, and neostriatum are excitatory and appear to use glutamate as a neurotransmitter (Kita and Kitai, 1987; Nakanishi et al., 1987; Smith and Parent, 1988; Albin ct al., 1989; Grocncwegen and Berendse, 1990; Robledo and Feger, 1990; Brotchie and Crossman, 1991; Price et al., 1993).

The effects of glutamate are mediated through ionotropic receptors, which form ligand-gated ion channels, and metabotropic receptors (mGluRs). MGluRs are coupled to alterations in cAMP formation (Aramori and Nakanishi, 1992; Schoepp et al., 1992; Tanabe et al., 1992, 1993; Winder and Conn, 1992; Winder and Conn, 1993), phosphotidylinositol (PI) turnover (Schoepp et al., 1990; Houamed et al., 1991; Masu et al., 1991; Abe et al., 1992), activation of phospholipase D (Boss and Conn, 1992), and modulation of ion channel activity (see Schoepp and Conn, 1993, for review). Ionotropic receptors are believed to mediate the majority of conventional fast excitatory transmission in the CNS. Metabotropic receptors have been implicated in the maintenance of more long-term processes such as synaptic plasticity and remodeling. This has becn demonstrated most clearly in studies of hippocampal function, where mGluRs are thought to have a role in long-term potentiation (Aronica et al., 1991; Bashir et al., 1993; Bliss and Collingridge, 1993). MGluRs have also been implicated in synaptic plasticity in the cerebellum (Linden et al., 1991) and striatum (Calabresi et al., 1992a).

Several studies have provided evidence for the presence of mGluRs in the basal ganglia. Ligand binding studies have demonstrated two distinct pharmacological types of metabotropic glutamate binding sites with different distributions in the basal ganglia nuclei (Albin et al., 1992; Catania et al., 1993). Quisqualate, an mGluR agonist, has been shown to stimulate release of inositol phosphates from striatal neurons in culture (Sladeczak et al., 1985, 1988).

1-Aminocyclopentane-1S,3R-dicarboxylic acid (ACPD), a more selective mGluR agonist, causes protein kinase $C$ acti- 
Table 1. Sequences of oligodeoxyribonucleotide probes used for in situ hybridization and the amino acid residues of the mGluRs to which they are complementary

\begin{tabular}{ccl} 
mGluR & Amino acids & Sequence $\left(5^{\prime}-3^{\prime}\right)$ \\
\hline mGluR1 Probe $1^{a}$ & $484-498$ & CCC CAC GTG GAC ATA GTC ATA GCG ATT AGC TTC TGT GTA CTG CAG \\
Probe 2 & $875-888$ & AGA ATT GGC ATT CCC TGC CCC GGG CTT CTT TCT CCG GAA AAT \\
mGluR2 Probe $1^{a}$ & $123-137$ & GGT GAC AGC TGT AGG AGC ATC ACT GTG GGT GGC ATA GGA GCC ATC \\
Probe 2 & $426-440$ & CTC ATC GTC AGT ATC TGC TGG GCG AAA GGG GGC GTC AAA CTT GAC \\
mGluR3 Probe $1^{a}$ & $841-855$ & CTG AGA ATA GGT GGT TGC AGT TCC GCT GAC GCT GAA CCT GTT GAG \\
Probe 2 & $364-378$ & GGC CAG GTG CTT GTC ACA AAC CTG TCT GTG GTT TCT CTT GTT CTG \\
mGluR4 Probe $1^{a}$ & $881-892$ & GGT CTC CAG GTT CTC ACA CAG CTC TGA TTT GGC TTC CCC ATT GGG \\
Probe 2 & $451-465$ & GAA GGT TAC AGG GTT CCC CGC AAT GCC TGA GAA GTT GAC GTT CCT \\
mGluR5 Probe $1^{a}$ & $124-138$ & GGA GCG GAA GGA AGA AGA TCC ATC TAC ACA GCG TAC CAA ACC TTC \\
Probe 2 & $4-19$ & GCA CTC CCT CGT ACA TCT TCT TTC AGA AGT AGG ACT GAC AGG ATC
\end{tabular}

${ }^{a}$ Probes used for detailed analysis and all figures presented in this article.

vation in the striatum in culture and in a Xenopus oocyte expression system (Manzoni et al., 1990). In an in vitro slice preparation, ACPD in low concentrations decreases striatal synaptic potentials mediated by glutamate, while higher concentrations of ACPD elicit excitatory responses (Calabresi et al., 1992b). In addition to these short-term actions, $\mathrm{mGluR}$ activation has also been shown to be necessary for at least one type of plastic response in the striatum, long-term depression (LTD) (Calabresi et al., 1992a).

Recent molecular studies of mGluRs have revealed a family of at least fivc rcceptors, named mGluR1-mGluR5 (Houamed et al., 1991; Masu et al., 1991; Abe et al., 1992; Pin et al., 1992; Tanabe et al., 1992), which can be divided into groups based on their proposed pharmacology and effector systems (Nakanishi, 1992). The group 1 receptors, mGluR 1 and mGluR5, increase the metabolism of PI to diacylglycerol, which activates protein kinase $\mathrm{C}$, and inositol triphosphate, which mobilizes calcium $\left(\mathrm{Ca}^{21}\right)$ from intracellular stores (Houamed et al., 1991; Masu et al., 1991; Abe et al., 1992). MGluR1 also stimulates cAMP formation and arachidonic acid release in stably transfected mammalian cells (Aramori and Nakanishi, 1992). Quisqualate is the most potent agonist for mGluR 1 and mGluR5, followed by glutamate. ACPD is the least potent $\mathrm{mGluR}$ agonist for this group.

The activation of both group 2 and group 3 mGluR receptors inhibits forskolin-stimulated cAMP formation (Tanabe et al., 1992, 1993), but these receptors differ in pharmacology. The group 2 receptors, mGluR2 and $m$ GluR3, respond well to glutamate and ACPD, and weakly to quisqualate (Tanabe et al., 1992, 1993). The most potent agonist for the group 3 receptor, mGluR4, is 2-amino-4-phosphonobutyrate, followed by glutamate (Tanabe et al., 1993). ACPD and quisqualate are probably weak mGluR4 agonists (Tanabe et al., 1993).

Previous investigations employing Northern blot (Houamed et al., 1991), in situ hybridization (Masu et al., 1991; Shigemoto et al., 1992; Tanabe et al., 1992, 1993; Ohishi et al., 1993), and immunocytochemistry (Martin et al., 1992; Fotuhi et al., 1993) have indicated the presence of all five mGluRs in the rat basal ganglia. As pharmacologically defined metabotropic binding sites are differentially distributed across the basal ganglia, and the cloned mGluRs themselves have distinct pharmacological profiles, we hypothesized that the mGluR messages are not only present in basal ganglia nuclei but have distinct regional patterns of expression that would in turn help elucidate the functional roles of individual mGluRs in the basal ganglia system. In addition, the internal complexity of the basal ganglia, particularly the anatomical and chemical partitioning of the striatum, suggested that mGluRs might exist in subpopulations of neurons within basal ganglia nuclei and, thus, again be implicated in the functioning of distinct pathways. We have used in situ hybridization with novel oligodeoxyribonucleotide probes in serially adjacent sections to construct a detailed picture of the differential distributions of mGluR gene expression in the basal ganglia at both the regional and cellular levels. The results provide insight into the importance of the mGluRs in the physiology of the basal ganglia and suggest possible roles for metabotropic receptors in basal ganglia function and disease.

\section{Materials and Methods}

Oligodeoxyribonucleotide probes were designed based on five published mGluR cDNA sequences (Houamed et al., 1991; Masu et al., 1991; $\Lambda$ be et al., 1992; Tanabe et al., 1992). Probes were targeted to regions where homology between the mGluRs was minimal. For each mGluR, at least two probes complementary to different regions of cDNA were prepared (Table 1). All probes for mGluR 1 were complementary to regions common to all published splice variants of mGluR 1 (Pin et al., 1992; Tanabe et al., 1992). A search of the GenBank and EMBL databases using the National Center for Biotechnology Information BLAST network service (Altschul et al., 1990) revealed no significant homology of these probes to known sequences other than the intended targets. All probes were synthesized with an Applied Biosystems 392 Synthesizer and purified by electrophoresis using a $12 \%$ polyacrylamide/ $8 \mathrm{M}$ urea gel. Prohes were $3^{\prime}$ end-labeled with ${ }^{35} \mathrm{~S}(\alpha)$-dATP (Du Pont-New England Nuclear; specific activity $>1000 \mathrm{Ci} / \mathrm{mm}$ ) using a Du Pont-New England Nuclear terminal deoxynucleotidyl transferase kit (NEP 100) Labeled probe was separated from the reaction mixture using a molecular sizing column (Stratagene).

All tissue was from adult male Sprague-Dawley rats (Charles River, 200-250 gm) killed by rapid decapitation. Brains were removed, flash frozen in isopentane, and stored at $-70^{\circ} \mathrm{C}$. Twelve micrometer cryostat sections were mounted on poly-L-lysine slides and stored at $-70^{\circ} \mathrm{C}$. For in situ hybridization, slides were warmed to room temperature, and then fixed in $4 \%$ paraformaldehyde in $0.1 \mathrm{~m}$ phosphate buffer, $\mathrm{pH} 7.4$ $(10 \mathrm{~min})$; washed in three changes of $0.1 \mathrm{M}$ phosphate buffer with $0.9 \%$ $\mathrm{NaCl}, \mathrm{pH} 7.4$ (PBS, $5 \mathrm{~min}$ each); acetylated in $0.1 \mathrm{M}$ triethanolamine, pH 8.0, with $0.25 \%$ acetic anhydride $(10 \mathrm{~min})$; washed in PBS $(5 \mathrm{~min})$ and dehydrated through graded ethanol solutions ( 2 min each). Hybridization was performed in a buffer of $50 \%$ formamide, $0.3 \mathrm{M} \mathrm{NaCl}$, $10 \mathrm{~mm}$ Tris pH 8.0,1 mM EDTA pH 8.0, 10\% dextran sulfate, $1 \times$ Denhardt's solution $(0.02 \%$ Ficoll, $0.02 \%$ polyvinylpyrolidone, $0.2 \mathrm{mg} /$ $\mathrm{ml}$ bovine serum albumin, Sigma), and $100 \mathrm{~mm}$ dithiothreitol. Labeled probes were added to a concentration of approximately $30,000 \mathrm{dpm} /$ $\mathrm{ml}$ of hybridization buffer. Sections were incubated in $60-100 \mu 1$ of hybridization solution under glass coverslips at $37^{\circ} \mathrm{C}$ overnight. Pre- 
hybridization and hybridization solutions were treated with diethylpyrocarbonate. After hybridization, coverslips were removed in $2 \times \mathrm{SSC}$ (standard saline citrate, $0.15 \mathrm{M} \mathrm{NaCl}, 0.015 \mathrm{~m}$ sodium citrate), and slides were washed in $2 \times \mathrm{SSC}$ [20 $\mathrm{min}$, room temperature $(\mathrm{RT})], 1 \times \mathrm{SSC}(10$ $\mathrm{min}, \mathrm{RT}), 0.5 \times \mathrm{SSC}(10 \mathrm{~min}, \mathrm{RT}), 0.5 \times \mathrm{SSC}\left(40 \mathrm{~min}, 60^{\circ} \mathrm{C}\right), 0.5 \times \mathrm{SSC}$ ( $10 \mathrm{~min}, \mathrm{RT})$, rinsed in two changes of $70 \%$ ethanol $(1 \mathrm{~min}$ each), and air dried. Slides were apposed to film ( $\beta$ max, Amersham) for 4 weeks, and then coated in liquid emulsion (Kodak NTB2 diluted 1:1 with deionized distilled water) and stored at $4^{\circ} \mathrm{C}$ for 3 months, developed, and counterstained with thionin. Specificity of hybridization was examined by adding a 25 -fold excess of unlabeled probe to the hybridization solution.

Quantitative image analysis was performed using a computer-assisted image analysis system (Imaging Research, Inc., St. Catharines's, Ontario). Serially adjacent sets of sections from six animals were used for quantitative analysis. All sections for a given probe were processed in a single experiment. For analysis of regions on film autoradiograms, absolutc optical density (AOD) for each region was defined as the average AOD over the entire region minus the background AOD of the film outside of the sections. AOD readings from at least three sections per animal were averaged. Averages from two to six animals for a given probe were.used to obtain a single mean and standard error value per region and were included in one-way repeated measures ANOVA analyses by region with post hoc pairwise comparisons, with a significance level of $99 \%$

Emulsion-dipped sections were examined using both bright-field and dark-field optics. Qualitative levels of labeling over cells in all regions were assessed in comparison to the brain region with the strongest labeling for that probe. Cells that exhibited signal greater than five times background were considered labeled. Quantitative analysis of cellular labeling was used to study the complex patterns of labeling found in the ncostriatum. Neurons in the dorsolateral striatum were visualized under bright-field illumination using a $100 \times$ water immersion lens. Neurons were identified by their size and visible cytoplasm as revealed by thionin stain. The image analysis system was used to define the borders of each neuron, and enumerate the silver grains overlying the cell. For each neuron, both the total number of grains and the area of the neuronal profile were measured. These data were used to calculate the number of grains per $1000 \mu \mathrm{m}^{2}$ of neuronal area.

\section{Results}

\section{Specificity of probes}

Probes to each of the five $\mathrm{mGluRs}$ produced unique patterns of hybridization in the rat brain (Fig. 1). Two probes were tested for each $\mathrm{mGluR}$, complementary to different regions of the same cDNA (Table 1). In each case, both members of the pair produced identical patterns of hybridization when tested on adjacent pairs of sections from at least two animals. The probe for each $\mathrm{mGluR}$ that gave the highest signal and lowest background levels in the comparison experiments was selected for subsequent detailed analyses (Table 1). For each of the probes, 25 fold excess cold probe added to the hybridization buffer abolished all signal on slides otherwise processed identically to experimental sections.

\section{mGluR1}

Several basal ganglia structures exhibited moderate labeling on film autoradiograms with an mGluR 1 probe, and all other basal ganglia nuclei exhibited lcvcls of signal significantly greater than white matter regions (Figs. 1A, 2). A low level of signal was observed in the striatum. Increasing amounts of expression were observed in the globus pallidus (GP), ventral pallidum (VP), entopeduncular nucleus (EPN) and olfactory tubercle (OT), subthalamic nucleus (STN), and the substantia nigra pars compacta $(\mathrm{SNc})$. The overall intensity of labeling in the substantia nigra pars reticulata ( $\mathrm{SNr}$ ) was lower than that in the SNc, and comparable to that of the striatum.
Microscopic examination of the emulsion-dipped, thionincounterstained sections showed that nearly all striatal and nucleus accumbens neurons exhibited a low but detectable level of signal (Fig. 3A). A small number of large polygonal neurons were observed in the striatum, none of which appeared to be labeled. Quantitative analysis of the striatal labeling confirmed the visual impression of a low uniform level of expression of mGluRl in striatal ncurons (Fig. 5). In the GP and VP, about $50 \%$ of neurons were moderately labeled, while the remainder had no detectable signal (Fig. 4A). EPN neurons were uniformly labeled. There were moderately high grain densities over all $\mathrm{SNr}$ neurons and moderate levels over all SNc neurons (Fig. 4C). The difference between the relative labeling observed on emulsion versus on film autoradiograms for these two structures reflects their difference in neuronal density, with the loosely packed SNr having higher numbers of grains per neuron but lower film signal, and the tightly packed $\mathrm{SNc}$ having lower grain densities and high film signal.

Outside the basal ganglia, the ventrolateral and ventromedial nuclei of the thalamus (VL/VM) were moderately labeled, while the reticular nucleus of the thalamus showed no detectable signal. The Purkinje cell layer of the cerebellum gave the highest signal of all areas measured, reflecting strong labeling of all Purkinje cells, while the granule cell layer showed moderate signal, with low labeling in the molecular layer. In the hippocampus, the CA3 area and the dentate gyrus labeled more strongly than CAl.

\section{$m$ GluR2}

MGluR2 was not expressed at levels detectable on film autoradiograms in most basal ganglia structures. Only the STN exhibited a moderate degree of labeling (Figs. $1 B, 2$ ). Microscopic examination confirmed the presence of moderately intense, homogeneous labeling of the neurons of this structure. Within the striatum, most neurons were not labeled; however, careful inspection revealed a small number of neurons, constituting 1$2 \%$ of the total population, which were moderately labeled (Figs. $3 B, 5)$. The majority of these were large and polygonal in shape. This observation was reflected in the quantitative analysis results: the neurons in the top percentile with regard to intensity of labeling (grains per neuronal area) had a mean area of 378 $\pm 73 \mu \mathrm{m}^{2}$ (mean $\left.\pm \mathrm{SEM}, n=6\right)$, which was more than twice that of the mean area of the striatal population as a whole, 170 $\pm 90 \mu \mathrm{m}^{2}(n=600)(p=0.0001$, Mann-Whitney nonparametric test). A similar small population of labeled neurons was observed in the nucleus accumbens, but these neurons were not as morphologically distinctive as those in the striatum. Neuronal labeling was not detected in the EPN, GP, VP, OT, SNc, or SNr.

Outside the basal ganglia, the area of strongest mGluR2 signal was the dentate gyrus of the hippocampus. Other areas of the hippocampus were not labeled. Another area of high signal was the granule cell layer of the cerebellum. Unlike mGluRl, the film autoradiograms of mGluR2 had a punctatc pattern of labeling in the cerebellar cortex. Examination of emulsion-dipped slides revealed that this labeling was concentrated over Golgi cells. Distinct layers of the neocortex expressed mGluR2, but because of the sharply laminated organization, the average optical density reading of the cortex was low. On emulsion-dipped slides, the densest cerebral cortical labeling was seen in layer IV granule cells, which were moderately labeled. Pyramidal cells in layers III and V were also labeled. 

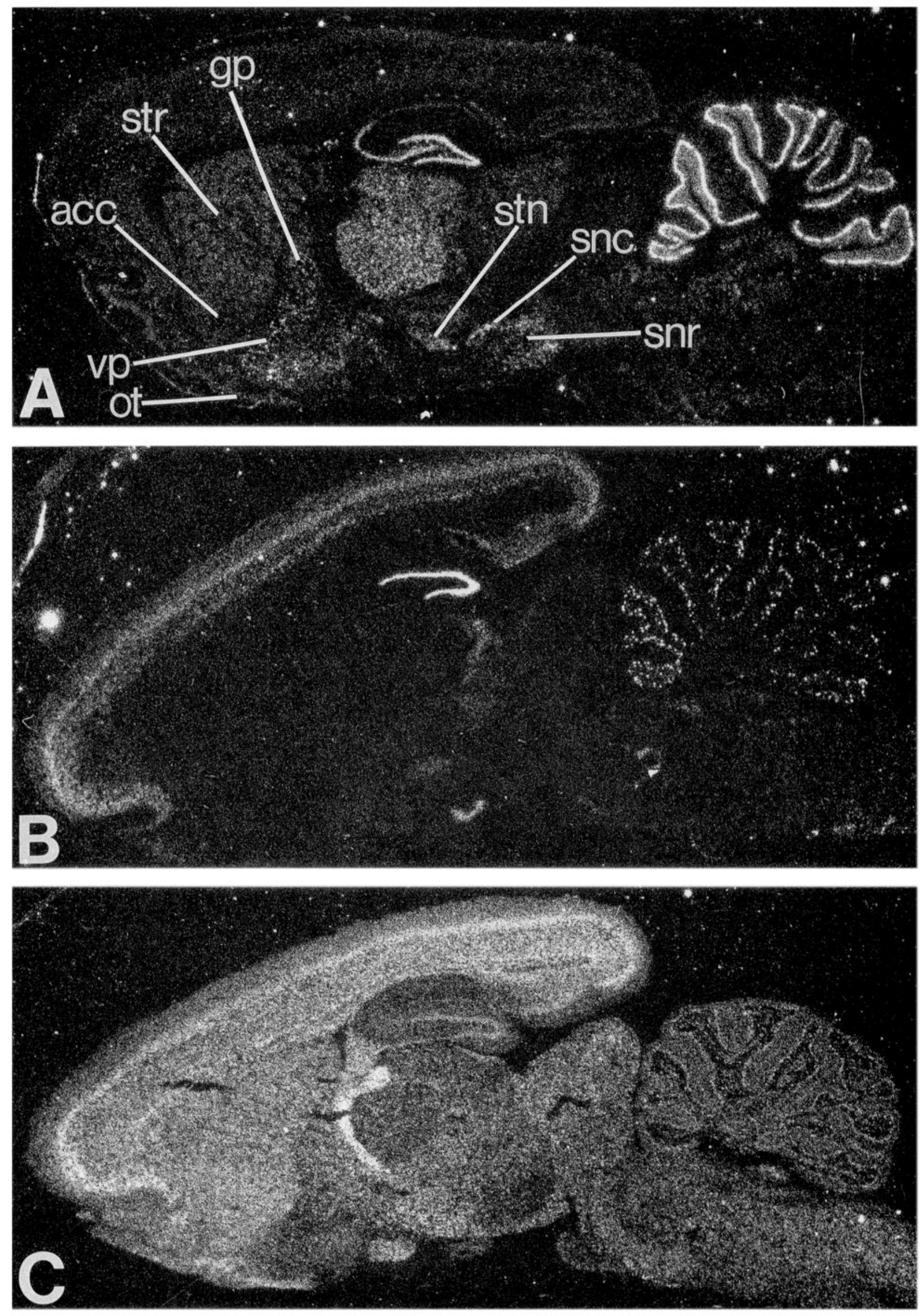

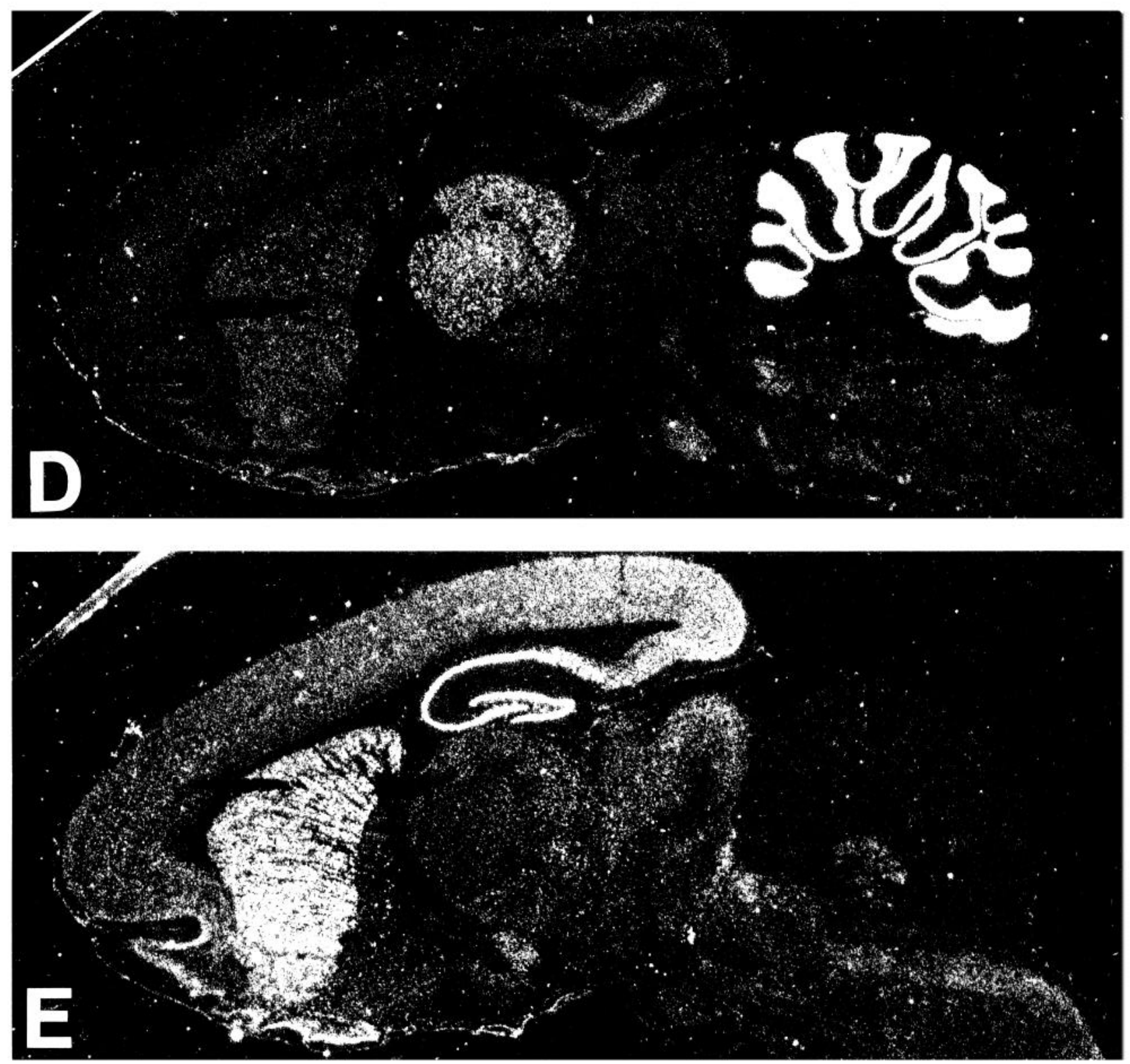

Figure 1. Distribution of expression of mGluRs: film autoradiograms of in situ hybridization distributions of probes for mGluR I (A), mGluR2 $(B)$, mGluR3 (C), mGluR4 $(D)$, and mGluR5 $(E)$. Acc, nucleus accumbens; $g p$, globus pallidus; $o t$, olfactory tubercle; snc, substantia nigra pars compacta; $s n r$, substantia nigra pars reticulata; $s t n$, subthalamic nucleus; str, striatum; $v p$, ventral pallidum.

\section{$m G / u R 3$}

In contrast to all of the other mGluRs, mGluR3 expression was observed in glia as well as neurons. This was manifest on film autoradiograms as labeling of white matter regions (Fig. 1C), and on emulsion-dipped slides as labeling of both neuronal and glial profiles (Figs. $3 C, 4 B, D$ ). In the basal ganglia, the GP, VP, and EPN contained labeling only over presumed glial profiles.

The striatum and nucleus accumbens were particularly strongly labeled on film autoradiograms (Figs. $1 C, 2$ ). On emulsiondipped slides, the neurons in these regions were uniformly and moderately labeled (Fig. 3C), with the exception of a small number of large polygonal neurons, which were unlabeled. Quantitative analysis of the neuronal labeling in the striatum confirmed the visual impression of moderate homogeneous labeling of most neurons (Fig. 5). In addition to the neuronal labeling, there were numerous small, darkly stained nuclear profiles with scant cytoplasm, taken to be glial, some of which were strongly labeled (Fig. 3C). Neurons in the anterodorsal part of the $\mathrm{SNr}$ were labeled, while those in the more ventral part and the SNc neurons were not (Fig. 4D). In the STN, most of the signal lay over presumed glial profiles, but a low level of neuronal labeling was also present. The GP, VP, and EPN were labeled on film autoradiograms well above background, but appeared less densely labeled than surrounding white matter. Neurons in these nuclei were not detectably labeled on emulsiondipped slides (Fig. 4B), although labeled glia were present in each of these structures.

Outside the basal ganglia, the area of highest mGluR3 signal was the reticular nucleus of the thalamus (Figs. 1C, 2). Both neurons and glia in this nucleus were strongly labeled. The cortex also exhibited moderately high signal levels. Layer $\mathrm{V}$ pyramidal 

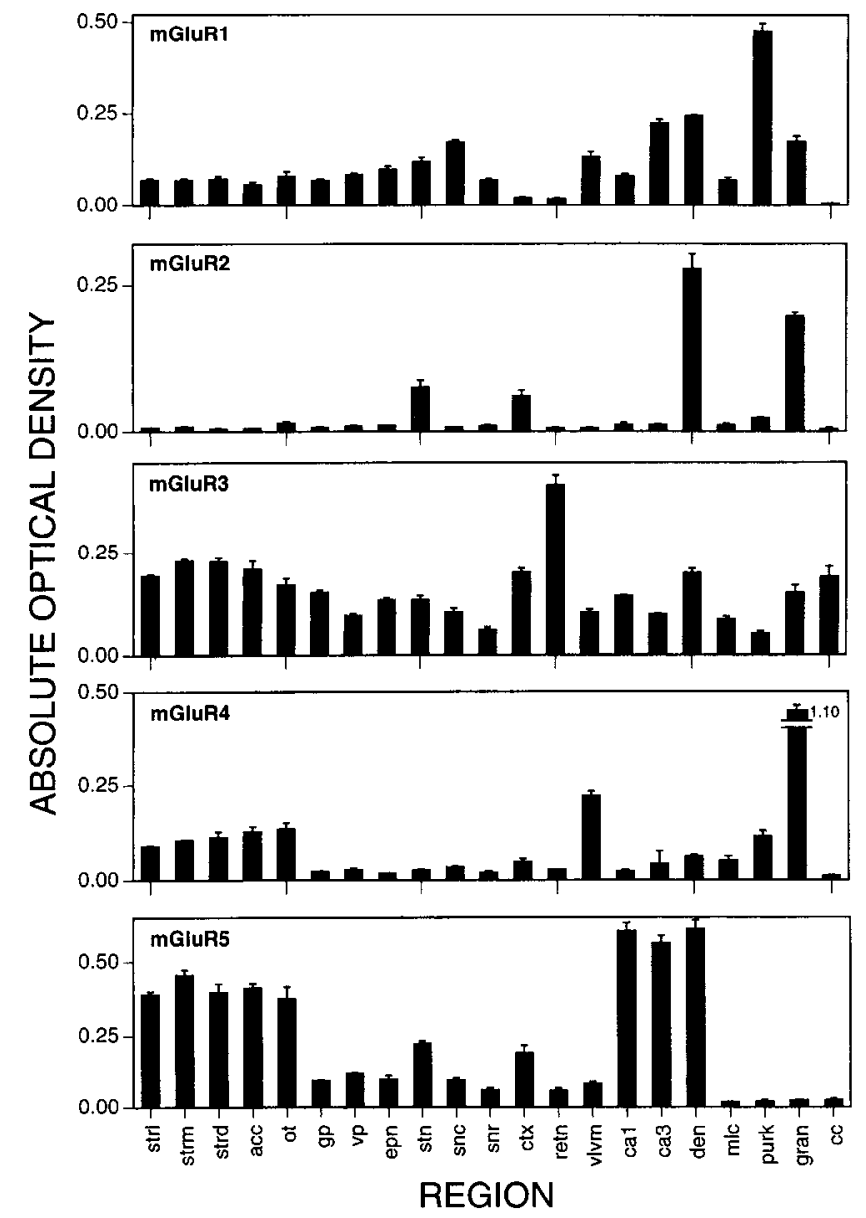

Figure 2. Absolute optical density (mean \pm SEM) of regions on film autoradiograms. Values represent the average of readings from three sections from each of two to six animals. strl, lateral striatum, defined on horizontal sections; strm, medial striatum, defined on horizontal sections; strd, dorsal striatum, defined on parasagittal sections; acc, nucleus accumbens; $o t$, olfactory tubercle; $g p$, globus pallidus; $v p$, ventral pallidum; epn, entopeduncular nucleus; $s t n$, subthalamic nucleus; $s n c$, substantia nigra pars compacta; $s n r$, substantia nigra pars reticulata; $c t x$, neocortex; retn, reticular nucleus of the thalamus; $v / v m$, ventrolateral and ventromedial nuclei of the thalamus; $c a 1$, cal pyramidal cells of the hippocampus; $c a 3$, ca3 pyramidal cells of the hippocampus; den, dentate gyrus granule cells of the hippocampus; $m l c$, cerebellar molecular layer; purk, cerebellar Purkinje cell layer; gran, cerebellar granular layer; $c c$, corpus callosum.

cclls had particularly high levels of labeling, and layer III pyramidal cells were also labeled. In the cerebellum, signal varied in the different layers. Moderately low labeling of the molecular cell layer reflected strong labeling of scattered stellate and basket cells. Golgi cells were also moderately labeled.

\section{mGluR4}

MGluR4 was not abundant in the basal ganglia. On film autoradiograms, labeling was seen in low but detectable levels in the striatum, nucleus accumbens, and OT (Figs. $1 D, 2$ ). Other basal ganglia structures gave no detectable signal. Examination of emulsion-dipped sections revealed very light labeling of SNc neurons and equivocal signal in $\mathrm{SNr}$ neurons. In contrast to mGluR 1 and -3 , the distribution of labeling in striatal neurons appeared heterogeneous, with many neurons labeled at a low level, some moderately labeled neurons, and some unlabeled neurons present (Fig. 3D). A small number of large polygonal neurons were observed, all of which appeared unlabeled. Quantitative analysis of the striatal labeling suggested that mGluR4 expression levels vary in striatal neurons, but distinct populations could not be resolved (Fig. 5).

Outside of the basal ganglia, mGluR4 displayed sharply differential patterns of expression (Figs. $1 D, 2$ ). The neocortex had a laminar distribution of labeling that, as for MGluR2, gave a low average film signal. On emulsion-dipped slides, layers III, $\mathrm{IV}$, and $\mathrm{V}$ were moderately densely labeled. The VL/VM area of the thalamus gave moderately high signal, while the reticular nucleus of the thalamus showed no labeling. There was only low labeling in the hippocampus, but there was very strong mGluR4 signal in the granule cell layer of the cerebellum. Examination of emulsion-dipped sections revealed that the cerebellar signal was largely confined to the cells of the granular layer and not detectable in Purkinje cells.

\section{mGluR5}

On film autoradiograms, the striatum, nucleus accumbens and OT exhibited high levels of mGluR5 expression (Figs. 1E, 2). The STN was moderately labeled. The VP signal was slightly higher than that of the GP or the EPN. Both the SNc and $\mathrm{SNr}$ were detectably labeled. On microscopic examination, mGluR5 signal, like mGluR4, appeared heterogeneous in the striatum and nucleus accumbens, with both labeled and unlabeled neurons present. Labeled and unlabeled neurons were often observed in clusters with others of similar type (Fig. 3E,F). Quantitative analysis revealed that about three-quarters of the dorsolateral striatal neurons were strongly labeled while the remaining $25 \%$ had few or no overlying grains (Fig. 5). The few large polygonal neurons which were observed were also unlabeled (Fig. $3 E$ ). To investigate further the apparent clustering of labeled and unlabeled neurons, in situ hybridization for mGluR5 was performed in coronally cut adult rat brain sections with serially adjacent sections processed for ${ }^{3} \mathrm{H}$-naloxone binding by the method of Abou-Khalil et al. (1984) to define striosome and matrix compartments. No simple relationship between neurons labeled with probes for mGluR5 and the compartments defined by ${ }^{3} \mathrm{H}$-naloxone binding was observed, and clusters of labeled and unlabeled neurons were present in both compartments. In the GP and VP, less than $50 \%$ of neurons exhibited moderately low labeling, while the remainder were unlabeled. In the $\mathrm{SNr}$, greater than $50 \%$ of neurons were moderately labeled with the rest unlabeled, while SNc neurons exhibited uniform very low signal. EPN neurons were all moderately labeled.

Outside of the basal ganglia, mGluR5 showed strong labeling in the granular and pyramidal regions of the hippocampus, and moderate labeling in all layers of the neocortex (Figs. $1 E, 2$ ). In the cerebellum, film autoradiograms revealed hybridization signal in the deep cerebellar nuclei, but not in any layer of the cerebellar cortex. On emulsion, low labeling of some Golgi cells was detected.

\section{Discussion}

Using oligodeoxyribonucleotide probes for in situ hybridization, we have observed differential expression of the genes encoding five mGluRs both within the structures of the basal ganglia and in other regions of the rat brain (Figs. 1, 2). The reproducibility of the observed patterns of labeling, the comparable patterns of expression observed with probes to different regions of the same 


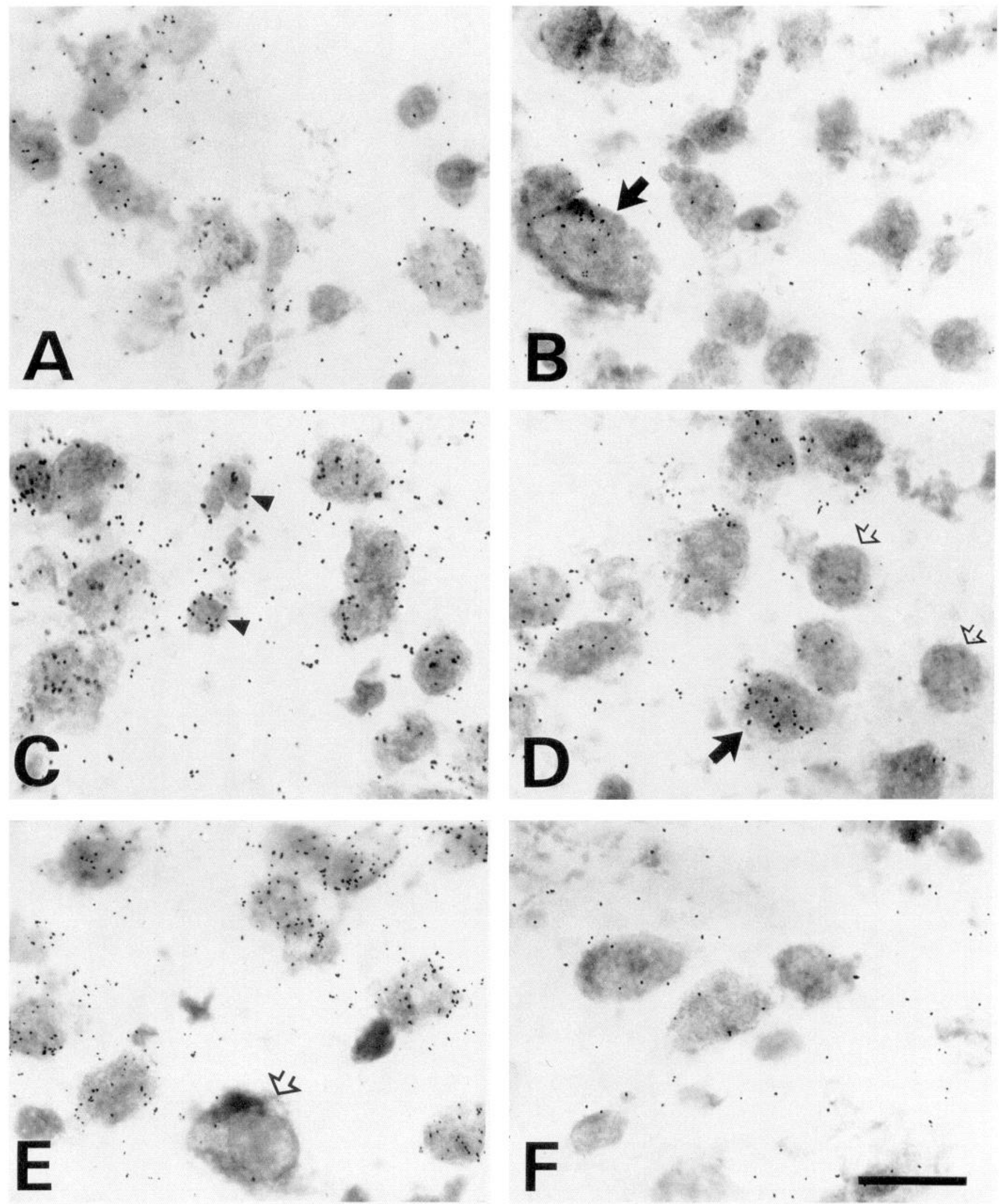

Figure 3. Cellular localization of mGluRs in the striatum. Bright-field photomicrographs of emulsion-coated sections hybridized with probes for mGluR1 $(A)$, mGluR2 $(B)$, mGluR3 $(C)$, mGluR4 $(D)$, mGluR5 $(E)$, and mGluR5 ( $F$; from same section as $E$ ). $A$, MGluR1 labeling of striatal neurons is homogeneous. $B$, MGluR2 does not label the majority of neurons, though a small number of large polygonal neurons (solid arrow) are labeled. $C$, MGluR3 uniformly labels striatal neurons, and also strongly labels some glia (arrowheads). $D$, MGluR4 labels some neurons (solid arrow), while others are unlabeled (open arrows). $E$ and $F$, MGluR5 labels the majority of striatal neurons $(E)$, but in an adjacent region of the same section $(F)$, a cluster of unlabeled neurons is present. Large polygonal neurons are not labeled $(E$, open arrow). Scale bar, $20 \mu \mathrm{m}$. 


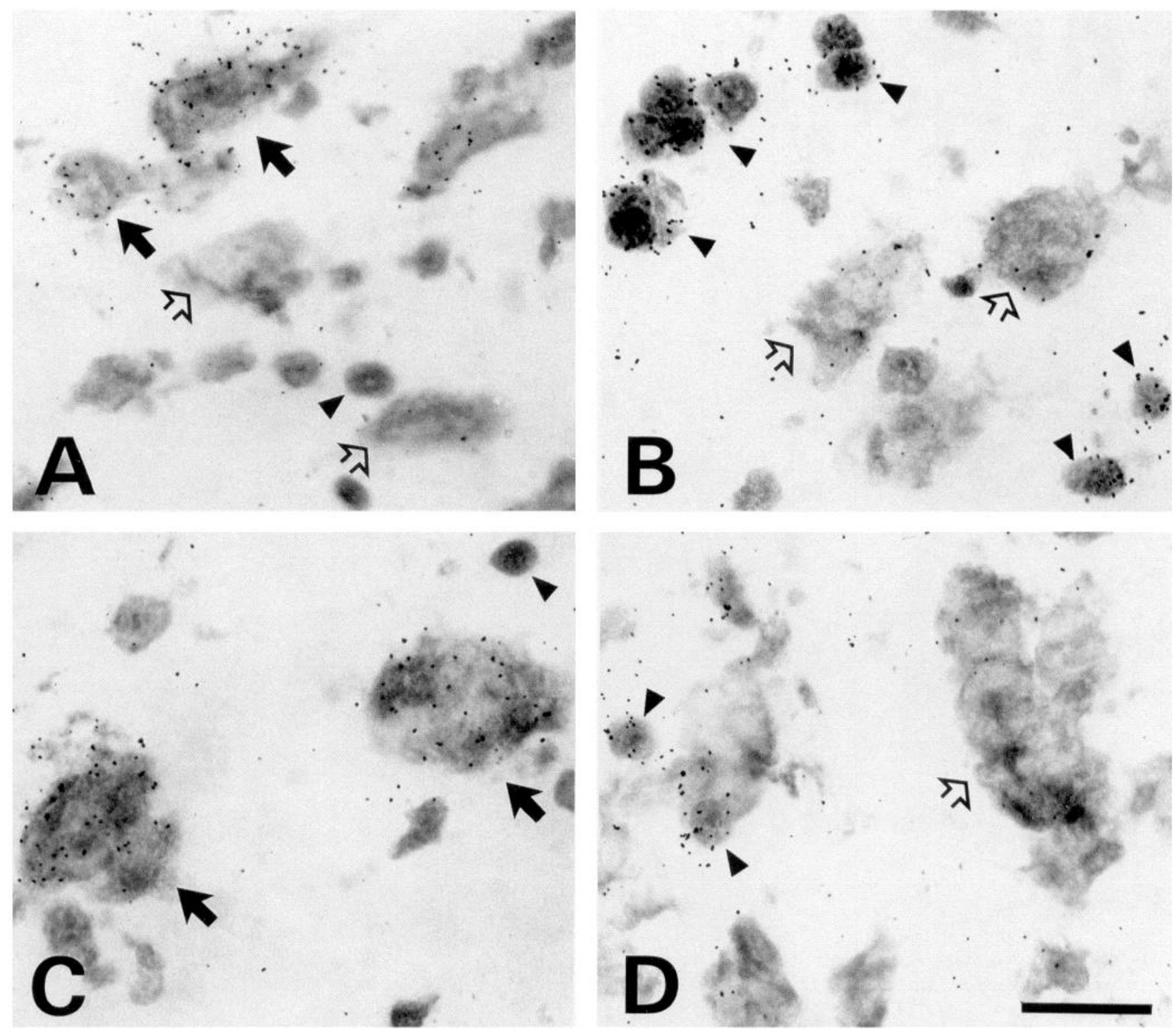

Figure 4. Cellular localization of mGluR1 and mGluR 3 expression in GP and SNc. A, MGluR1 labels about $50 \%$ of neurons in the GP (solid arrows), while the remaining neurons (open arrows) are unlabeled. $B$, MGluR3 labels glia (arrowheads) in the GP, but leaves all neurons unlabeled (open arrows). $C$, MGluR1 labels all of the large dopaminergic cells of the SNc (solid arrows), but glia (arrowhead) are not labeled. D, In contrast, mGluR3 shows strong labeling of glia (arrowheads) in the SNc, while neurons are unlabeled (open arrow). Scale bar, $20 \mu \mathrm{m}$.

receptor, and the low homology of the sequences of the different mGluR cDNAs in the regions selected for the probes provide confidence in the ability of this technique to distinguish the expression of the different genes. The observed absence of signal with excess cold probe demonstrates the saturability of binding, although it is not informative with regard to cross-hybridization. The results we have obtained are in general similar to those obtained by others employing Northern analysis (Houamed et al., 1991; Abe et al., 1992; Condorelli et al., 1992; Tanabe et al., 1992, 1993), immunohistochemistry (Martin et al., 1992), and in situ hybridization (Masu et al., 1991; Abe et al., 1992; Shigemoto et al., 1992; Tanabe et al., 1992, 1993; Ohishi et al., 1993). Ours is the first systematic study of all five cloned mGluRs using specific oligonucleotide probes. Previous in situ hybridization studies have employed riboprobes for single mGluRs, which may be more sensitive but less specific than oligonucle- otide probes when used to distinguish among the members of a highly homologous gene family (Lewis and Baldino, 1990). In addition, our study provides quantitative data on the regional and cellular expression of mGluRs within the basal ganglia, which allows direct comparison with previous studies employing ligand binding techniques, and provides additional information on the cellular organization of $\mathrm{mGluR}$ expression within the basal ganglia, particularly the unanticipated complexity of mGluR expression within the neostriatum (Figs. 3, 5).

We have found that in situ hybridization with oligonucleotide probes using the methods described produces highly reproducible results. In sections hybridized in a single experiment, the variability in the intensity of labeling as measured by film autoradiography of a given region both between sections from the same animal and between sections from different animals is quite small (Fig. 2). In our experience, the variability between 

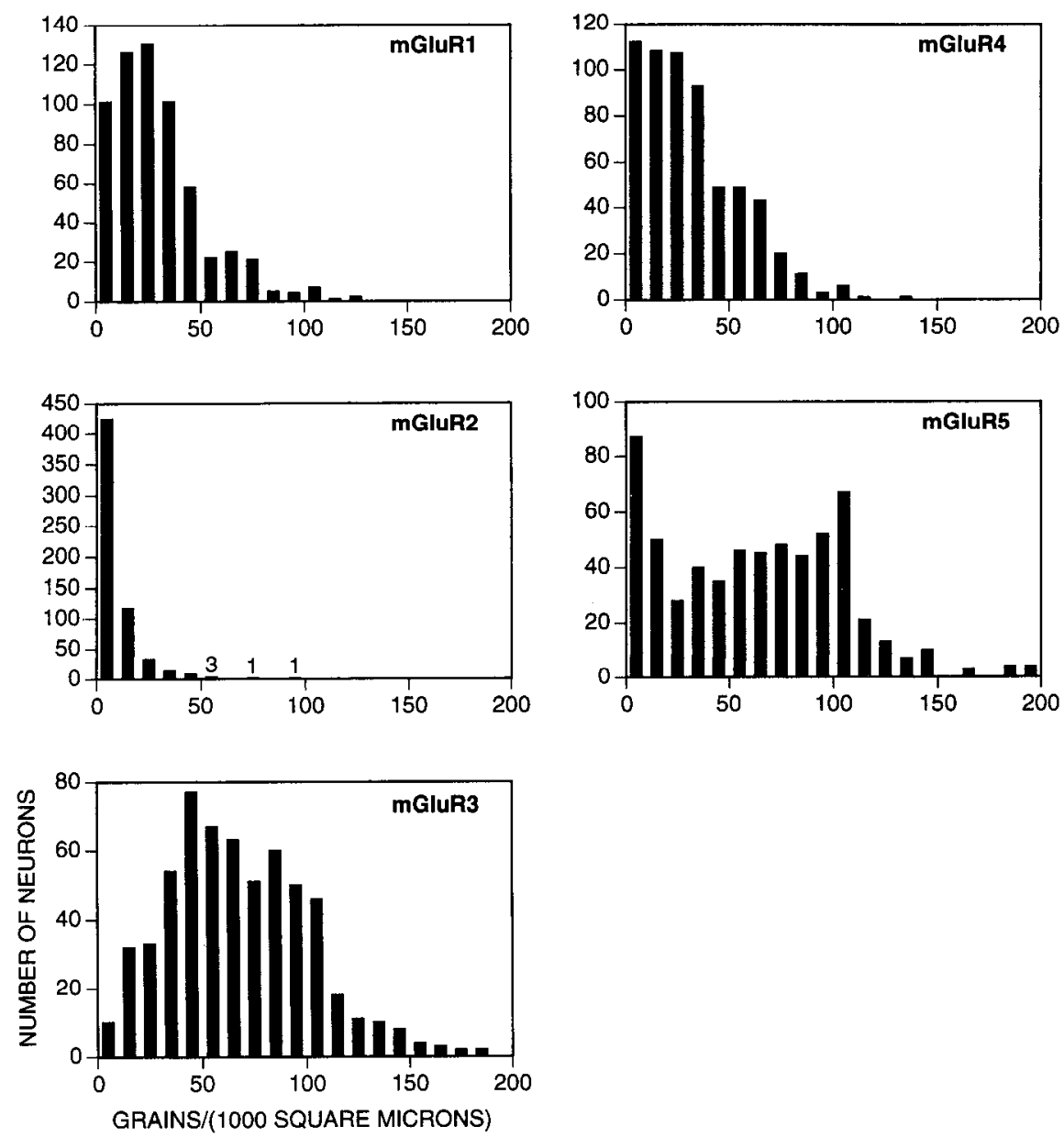

Figure 5. Frequency distributions of cellular labeling intensity of dorsolateral striatal neurons. In all cases $a b$ scissa indicates grains per $1000 \mu \mathrm{m}^{2}$, in bins of tens, and ordinate indicates number of striatal neurons per bin, as shown on the lower left. Numbers within the $m$ GluR2 graph indicate number of neurons in a given bin. For each probe, 200 neurons in the dorsolateral striatum were analyzed on each of three slides taken from two or three different animals, for a total of 600 neurons per probe. The intensities of labeling of mGluR1 and mGluR3 appear distributed around the mean; the probe for mGluR3 labeled striatal neurons more strongly than did the probe for mGluR1. The probe for mGluR2 produced no grains over the vast majority of neuronal profiles, although a few neurons with 50-100 overlying grains per 1000 $\mu \mathrm{m}^{2}$ were observed. The probe for mGluR 4 produced a broad distribution of intensity, with a large number of neurons having only a few overlying grains. No distinct populations were resolved. In the case of mGluR5, a bimodal distribution of labeling intensity was observed, reflecting the presence of labeled and unlabeled populations of neurons (Fig. $3 E, F$ ). experiments is somewhat larger, probably because of differences in the specific activity of the probe, but is still on the order of $10 \%$ or less. Previous studies have established that the optical density of film autoradiograms is an accurate reflection of the density of the radioactive label when ${ }^{35} \mathrm{~S}$ is employed (Miller, 1991). Thus, the quantitative optical density data we have obtained is likely to be a fairly accurate reflection of the relative distribution of mRNA for the individual mGluRs within the brain. Similarly, the density of grains present on an autoradiographic emulsion is well correlated with the density of radioactive labeling, although some variation between slides and even within some regions of the same slide may occur because of local variation in the thickness of the emulsion (Young and Kuhar, 1986).

Comparison of the hybridization signal produced by different probes in the same region of the brain is more problematic, because the signals may be affected by not only the specific activity of the probes, but also the relative preservation of the different mRNAs during the procedure, and efficiency of hybridization of each probe to its target. In the case of mGluR2mGluR5 (Abe et al., 1992; Tanabe et al., 1992, 1993), regional Northern analysis has been performed, and in general supports the distribution and relative intensity of expression of messages seen in this study. Similar comparative studies of other genes expressed in the brain using in situ hybridization and Northern analysis have also demonstrated a close correlation between the results obtained with these two techniques (Sokoloff et al., 1990;
Moriyoshi et al., 1991); however, Northern analysis does not allow a high degree of anatomical localization, and does not entirely circumvent concerns about differential preservation of mRNA and efficiency of hybridization. We have made every effort to ensure comparability of the signals obtained with our probes, including the use of probes of similar size and composition and hybridization under identical conditions on serially adjacent sections, but still some caution must be employed in the comparison of signals produced by dissimilar probes, and the signals cannot be taken as a strict reflection of the underlying mRNA copy number. With this in mind, it should be noted that in general, the intensity of labeling produced by thesc probes for the mGluRs is lower than the signal we have obtained with probes for other neurotransmitter receptors, such as the NMDA receptor (Standaert et al., 1994), possibly reflecting a lower level of mRNA expression for the mGluRs.

\section{$M G l u R$ expression in the basal ganglia}

The striatum and nucleus accumbens exhibit the most complex pattern of mGluR expression. MGluR5 and mGluR4 have inhomogeneous patterns of striatal expression, mGluR1 and mGluR 3 are expressed homogeneously, and mGluR2 is absent from all but a very small number of striatal neurons. Probes for mGluR5 produce strong neuronal labeling in the striatum and nucleus accumbens relative to the rest of the brain, and label these regions more intensely than the other mGluR probes examined. Distinct populations of both strongly labeled and un- 
labeled neurons organized into clusters were evident by visual inspection (Fig. $3 E, F$ ). This impression of distinct populations was supported by the bimodal intensity of cellular labeling revealed by quantitative analysis (Fig. 5). A heterogeneous pattern of expression was also observed in these nuclei for mGluR4 (Fig. $3 D$ ). While many neurons appeared unlabeled with probes for mGluR4 (Fig. 5), the spatial clustering characteristic of mGluR 5 was not evident. MGluR 1 and mGluR 3 expression by striatal and nucleus accumbens neurons was detectable at homogeneously low (Figs. $3 A, 5$ ) and moderate (Figs. $3 C, 5$ ) levels, respectively. MGluR2 did not label the majority of striatal or nucleus accumbens neurons, but did label a morphologically distinct class of large polygonal striatal neurons (Fig. $3 \mathrm{~B}$ ), comprising $1-2 \%$ of the total striatal population (Fig. 5). These neurons were identifiable in sections hybridized with probes to the other four mGluRs but were never observed to be labeled with these probes. It seems likely that these distinctive cells correspond to cholinergic interneurons (Phelps et al., 1985; Phelps and Vaughn, 1986).

Although probes for both mGluR5 and mGluR4 appear to label distinct populations of striatal neurons, it is not clear whether these populations correspond to any of the previously recognized compartments of the striatum. One striatal compartment, the striosome, makes up about $10 \%$ of the striatum, and can be distinguished from the surrounding matrix by histochemical, immunocytochemical, and ligand binding techniques (for reviews, see Graybiel, 1990; Gerfen, 1992). Matrix and striosome divisions can be visualized at the level of film autoradiograms. We compared mGluR5 in situ hybridization on film and emulsion-dipped slides with ${ }^{3} \mathrm{H}$-naloxone binding in scrially adjacent coronal sections and observed labeled cell clusters in both striosome and matrix areas; therefore, mGluR5 expression is probably not a simple reflection of the matrix versus striosome compartments. MGluR4 striatal labeling also does not exhibit striosome and matrix boundaries on film, and on microscopic examination does not appear clustered like mGluR5. Another type of striatal compartment is defined by the efferent projections of the striatal neurons, predominantly to the GP and SNr. These different sets of projection neurons can be visualized with tracing studies or by examination of the specific neuropeptides colocalized with GABA in these neurons: enkephalin is most dense in GP afferents, while substance $P$ is predominantly localized to neurons projecting to $\mathrm{SNr}$ (for review, see Gerfen, 1992). It is possible that double label in situ or tract tracing studies could reveal that the expression of mGluR4 or mGluR5 is segregated among these pathways. Altcrnatively, mGluR5 expression may be related to previously described morphological aggregates of striatal neurons (Paskevich et al., 1991).

We found that in the pallidum, mGluR $I$ and -5 are the predominant subtypes expressed, with $\mathrm{mGluR} 3$ also present in glia and some SNr neurons. MGluR I and mGluR5 are both present in the VP, GP, EPN, and SNr, with higher film autoradiogram signal in the VP than the GP. While both mGluR 1 and mGluR 5 signals in these structures are low compared to other brain regions, mGluR 1 expression in all pallidal structures is comparable to or greater than its expression in the striatum, while mGluR5 pallidal labeling is much lower than its striatal signal. On a cellular level, mGluR 1 and -5 are both uniformly expressed in all EPN neurons, but only in a subset of neurons in the GP and VP. MGluR1 is observed in about half of the GP and VP neurons (Fig. $4 A$ ), with mGluR5 seen in fewer than 50\%. MGluR3 is expressed only in glia in these three nuclei (Fig. 4B). In the $\mathrm{SNr}$, probes for mGluR 1 label all neurons moderately densely, but mGluR 5 probes label only somewhat more than $50 \%$ of SNr neurons, leaving others unlabeled. Probes for mGluR3 label neurons in the anterodorsal area of the $\mathrm{SNr}$ only while neurons in the more caudal areas are unlabeled. MGluR2 and mGluR4 are not detectable in any of these four nuclei.

The SNc expresses moderate levels of mGluR 1 (Fig. 4C) and low levels of mGluR5. The mGluR 1 labeling in the SNc is the highest level of mGluR1 film signal in the basal ganglia nuclei and higher than the neuronal mGluR 1 signal in the striatum or nucleus accumbens, although it is still much less intense than the Purkinje cells of the cerebellum (Fig. 2). MGluR5 SNc labeling is low compared to that of the striatum and STN. In addition, weak mGluR4 signal could be detected in SNc neurons. MGluR3 was expressed only in glia in the SNc (Fig. 3D), and mGluR2 expression was not detected.

The STN is unique among the basal ganglia in that neurons in this structure express readily detectable levels of mGluR2 (Figs. 1 $B, 2$ ). In addition, moderate levels of mGluR 1 and mGluR5 are present, with a low amount of mGluR3 neuronal signal and high mGluR3 glial expression.

\section{Relationship of metabotropic ligand binding sites to patterns of gene expression}

Autoradiographic ligand binding techniques have been used to study the organization of metabotropic binding sites in the basal ganglia. Two sites have been resolved by these methods: a ${ }^{3} \mathrm{H}$ glutamate site displaced by $2.5 \mu \mathrm{M}$ quisqualate in the presence of $\mathrm{D}, \mathrm{L}-\alpha$-amino-3-hydroxy-5-methymethyl-4-isoxazole-4-pro-

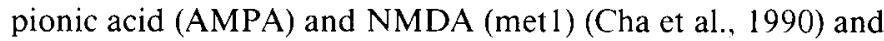
a second site that cannot be displaced by NMDA, kainate, or $2.5 \mu \mathrm{M}$ quisqualate (NNKQ) (Greenamyre et al., 1990). Recent studies have found that the majority of NNKQ binding can be displaced by the specific mGluR agonist $1 S, 3 R$-ACPD (ACPD) but not by the $1 R, 3 S$ isomer. This suggests that the majority of NNKQ binding represents a second type of metabotropic receptor ligand site (met2) (Catania et al., 1993).

The pharmacological profile of the met 1 site, which has a high affinity for quisqualate and lower affinity for ACPD, matches that of the group 1 receptors, mGluR 1 and mGluR5 (Masu et al., 1991; Nakanishi, 1992). The pattern of group 1 receptor gene expression we report is also similar to the previously observed distribution of met 1 binding in the basal ganglia (Cha et al., 1990; Albin et al., 1992). Metl binding is high in all areas of the striatum. We observed that mGluR 5 is strongly expressed in the striatum, though mGluR 1 is present only at modest levels. There is moderate met 1 binding in the VP and STN, moderately low binding in substantia nigra, and low binding in GP and EPN. Both mGluR 1 and mGluR5 are moderately expressed in the STN. Both genes are expressed at higher levels in VP than $\mathrm{GP}$, and both are expressed in the substantia nigra at levels comparable to STN and VP, with mGluR 1 relatively more prominent in these nuclei.

NNKQ binding represents glutamate binding sites with low affinity for quisqualate. I ike the metl site, NNKQ binding is also enriched in the striatum (Albin et al., 1992). The majority of this striatal NNKQ binding can be displaced by ACPD (Catania et al., 1993); thus, the pharmacological properties of these striatal sites resemble those of the group 2 receptors, mGluR2 and mGluR3 (Tanabe et al., 1992, 1993). We have observed moderately abundant mGluR 3 expression by both neurons and 
glia in the striatum. MGluR3 may account for a proportion of the striatal NNKQ binding; however, the level of total (neurons and glia) mGluR3 striatal film signal is comparable to that of the GP, while the level of NNKQ binding in the striatum is nearly twofold that in the GP, suggesting that intrinsic mGluR3 alone does not fully account for NNKQ binding in the striatum. MGluR2 is only expressed in a very small number of striatal ncurons, and thus intrinsic striatal mGluR2 expression seems unlikely to make a major contribution to striatal NNKQ binding. Although mGluR4 is expressed in striatal neurons, the pharmacology of this receptor differs from the group 2 receptors in that it has a low affinity for ACPD and is insensitive to quisqualate (Nakanishi, 1992). Therefore, mGluR4 is unlikely to be responsible for a large fraction of striatal NNKQ binding, though it could account for the small portion of NNKQ binding that cannot be displaced by ACPD.

Outside of the striatum, there is also a disparity between the distribution of NNKQ binding (Albin et al., 1992) and the expression of mGluR2-mGluR4. There is moderate NNKQ binding in the GP, VP, and substantia nigra, all areas in which we observed little or no neuronal mGluR2, -3 , or -4 expression. It is possible that glial mGluR3 receptors may account for some of the NNKQ binding in these structures. NNKQ binding is low in STN, where mGluR2 signal is moderate, higher than in any other basal ganglia structure.

One explanation for the apparent discordance of ligand binding sites and mGluR gene expression in the basal ganglia is the potential presynaptic localization of mGluRs. For example, NNKQ (met2) binding is high in the striatum despite relatively low striatal expression of group 2 transcripts. High mGluR3 signal was observed in cortex, particularly layer $\mathrm{V}$ pyramidal cells, which provide a major glutamatergic input to the striatum. Presynaptic mGluR 3 receptors on these corticostriatal afferents could account for some NNKQ striatal binding. Similarly, mGluR2 expression is observed at low levels in cortical pyramidal cells, and presynaptic $\mathrm{mGluR} 2$ receptors could also be present on corticostriatal terminals (Ohishi et al., 1993). MGluR2 was also observed at moderate levels in the STN, where NNKQ binding is low, but was virtually absent in STN projection targets where NNKQ binding is moderate (pallidal and nigral nuclei) or high (striatum). Presynaptic mGluR2 receptors on STN terminals may also account in part for NNKQ binding in the substantia nigra, GP, and VP and could contribute to striatal NNKQ binding.

A presynaptic location has been demonstrated for mGluRl, which has been shown by immunohistochemistry to be present in presynaptic terminals in the striatum (Fotuhi et al., 1993). Our data suggest that one potential source of these mGluR1containing afferents are the dopaminergic projections of the SNc. Such a location could account for the ability of glutamate to enhance dopamine release in striatal slices (Giorguieff et al., 1977) and in vivo (Chéramy et al., 1986).

An alternative explanation for the differences between ligand binding and in situ hybridization distributions is that the ligand sites represent a composite of known and as yet unidentified sites. Two additional types of mGluRs, a retinal form (Nakanishi, 1992) and a subtype predominantly located in olfactory bulb (Saugstad et al., 1992), have been described in preliminary reports. Other members of this receptor family may be found in the future.

Pharmacological agents specific for the individual mGluRs will be necessary to correlate binding data accurately with spe- cific $\mathrm{mGluR}$ protein distributions. Shinozaki and colleagues have recently synthesized conformationally restricted glycine compounds, eight stereoisomers of $\alpha$-(carboxycyclopropyl)glycine (CCG), which exhibit different affinities for specific glutamate receptors (Ohfune et al., 1993). Two of these compounds, L-CCG-I and L-CCG-II, are selective agonists for metabotropic receptors (Ishida et al., 1990), with $\mathrm{L}-\mathrm{CCG}-\mathrm{I}$ being much more potent at mGluR2 than at mGluR 1 or $m$ GluR 4 receptors (Hayashi et al., 1992). Compounds such as these will allow better investigation of the relationship between the distributions of ligand binding subtypes and in situ hybridization distributions of specific mGluRs.

\section{Functions of metabotropic receptors in the basal ganglia}

Metabotropic receptors have been implicated in several behavioral functions mediated by the basal ganglia. Unilateral injection of the mGluR agonist ACPD into the striatum of rats induces contralateral rotational behavior (Sacaan et al., 1991, 1992). The behavior begins $1 \mathrm{hr}$ postinjection, reaches a plateau at 3-6 hr, and ends by $24 \mathrm{hr}$. The effect is specific to the striatum: injection of ACPD into the GP instead of the striatum produces much less rotational behavior (Sacaan et al., 1991). An intact dopaminergic system is required for this behavioral effect (Sacaan et al., 1992), and levels of dopamine metabolites in the striatum increase with turning behavior, which suggest that increased dopamine release occurs. The location and type of metabotropic receptor or receptors that mediate this effect are unknown. It is possible that ACPD acts directly on a presynaptic mGluR on striatal dopaminergic terminals to increase dopamine release and subsequent dopamine receptor activation. We have postulatcd such a location for mGluR 1 , discussed above; however, Sacaan and colleagues did not observe any increase in dopamine release by ACPD from striatal slices in vitro, and ACPD is a relatively poor agonist for mGluR 1 . Alternatively, this effect could be mediated indirectly, by postsynaptic striatal mGluRs such as mGluR5 or mGluR3, or by other potential presynaptic mGluRs such as $\mathrm{mGluR} 2$ or -3 on corticostriatal terminals (mGluR4 receptors, which may exist at both these locations, do not respond to ACPD).

Interaction of the metabotropic and dopaminergic systems in the striatum has also been demonstrated at the synaptic level. LTD can be produced in striatal neurons by tetanic stimulation of corticostriatal fibers in a slice preparation (Calabresi et al., 1992a). A lasting depression of synaptic potentials is observed only with postsynaptic depolarization and action potentials during tetanus, and activation of both $D_{1}$ and $D_{2}$ dopamine rcceptors is required. Striatal LTD is blocked by the mGluR antagonist 2-amino-3-phosphonopropionate (AP3), but not 2-amino-5-phosphonovalerate, an NMDA receptor antagonist, or bicuculline, a $\mathrm{GABA}_{\mathrm{A}}$ receptor antagonist. In the cerebellum (Ito et al., 1982), it has been shown that a postsynaptic mGluR is required for LTD at the parallel fiber-Purkinje cell synapse (Kano and Kato, 1987; Linden et al., 1991). Growing evidence, including physiological (Linden et al., 1991), in situ hybridization (Shigemoto et al., 1992), and immunohistochemistry (Martin et al., 1992; Fotuhi et al., 1993), indicates that mGluR1 mediates this effect in the cerebellum. We have found that mGluR 1 is expressed in all striatal neurons, and could mediate striatal LTD through a postsynaptic receptor similar to cerebellar LTD.

MGluRs may also play a role in the response of striatal neurons to injury. Striatal excitotoxic lesions produced by iono- 
tropic glutamate receptor agonists can be attenuated by prior decortication (Biziere and Coyle, 1978, 1979). In a recent study (Beal et al., 1993), toxicity of NMDA after decortication was restored by coinjections of ACPD, which is not toxic alone in normal or decorticated animals (Sacaan et al., 1991; Schoepp et al., 1992). Coinjection of AP3, a specific metabotropic antagonist, with ionotropic agonists in naive animals attenuates lesions in a dose-dependent manner. These results support a permissive or enhancing role for metabotropic receptors in striatal excitotoxicity (Aleppo et al., 1992; McDonald and Schoepp, 1992; Sacaan and Schoepp, 1992). ACPD has also been shown to attenuate NMDA toxicity in cortical cultures (Koh et al., 1991 a), though ACPD does not affect kainate or AMPA toxicity or produce any toxic effects alone in this in vitro system (Koh et al., $199 \mathrm{lb}$ ). Excitotoxicity is thought to require increased $\mathrm{Ca}^{2+}$ mobilization (Choi and Rothman, 1990); thus, the most likely mGluRs involved in this process are the presumed postsynaptic PI-linked group 1 receptors, mGluR 1 and mGluR5. Our results suggest that mGluR5 is very abundant in the striatum and, thus, seems likely to play a role in the enhancing mechanism of striatal injury. Whether metabotropic receptors also have a neuroprotective role in the adult striatum is unknown.

\section{Clinical implications}

Use of glutamatergic agents in the therapy of human disease has been proposed, but practical application of this proposal is hindered both by the abundance of glutamate receptors in all areas of the brain, including the basal ganglia, and the relative nonselectivity of available agents (Klockgether and Turski, 1989; Greenamyre and O'Brien, 1991). Identification of the unique distributions of specific glutamate receptors points to promising avenues of drug development. For example, we have observed that $\mathrm{mGluR} 1$ alone is relatively abundantly expressed by the dopaminergic neurons of the $\mathrm{SNc}$, suggesting that agents specific for $\mathrm{mGluR} 1$ receptors could be useful for regulating the function of this important structure. MGluR5 and mGluR4 exhibit selective expression in subpopulations of striatal neurons, suggesting that agonists specific for these receptors may have important effects on motor regulation.

Among the basal ganglia structures, mGluR2 is particularly prominent in the STN. In an earlier study we found that this structure also expresses a distinct subtype of the NMDAR1 glutamate receptor (Standaert et al., 1994). The STN has a potentially important role in the clinical syndrome of Parkinson's disease (Albin et al., 1989), and drug treatment targeting the STN or even surgical ablation of this nucleus has been proposed as therapy for Parkinson's disease (Bergman et al., 1990). Antagonists of mGluR2 may provide a pharmacological means of selectively altering the function of the STN.

\section{References}

Abe T, Sugihara $H$, Nawa $H$, Shigemoto R, Mizuno N, Nakanishi S (1992) Molecular characterization of a novel metabotropic glutamate receptor, mGluR5, coupled to inositol phosphate/ $\mathrm{Ca}^{2+}$ signal transduction. J Biol Chem 267:13361-13368.

Abou-Khalil B, Young AR, Penney JR (1984) Fvidence for the presynaptic localization of opiate binding sites on striatal efferent fibers. Brain Res 323:21-29.

Albin RL, Aldridge JW, Young AB, Gilman S (1989a) Feline subthalamic nucleus neurons contain glutamate-like but not GABA-like or glycine-like immunoreactivity. Brain Res 491:185-188.

Albin RL, Young AB, Penney JB (1989b) The functional anatomy of basal ganglia disorders. Trends Neurosci 12:366-375.
Albin RL, Makowice RL, Hollingsworth ZR, Dure LSI, Penney JB, Young AB (1992) Excitatory amino acid binding sites in the basal ganglia of the rat: a quantitative autoradiographic study. Neuroscience 46:35-48.

Aleppo G, Pisani A, Copani A, Bruno V, Aronica E, D'Agata V, Canonico PL, Nicoletti F (1992) Metabotropic glutamate receptors and neuronal toxicity. Adv Exp Med Biol 318:137-145.

Altschul S, Gish SF, Miller W, Myers E, Lipman D (1990) Basic local alignment search tool. J Mol Biol 215:403-410.

Aramori I, Nakanishi S (1992) Signal transduction and pharmacological characteristics of a metabotropic glutamate receptor, mGluR1, in transfected $\mathrm{CHO}$ cells. Neuron 8:757-765.

Aronica E, Frey U, Wagner M, Schroeder H, Krug M, Ruthrich H, Catania MV, Nicoletti F, Reymann KG (1991) Enhanced sensitivity of "metabotropic" glutamatc rcceptors after induction of long-term potentiation in rat hippocampus. J Neurochem 57:376-383.

Bashir ZI, Bortolotto ZA, Davies CH, Berretta N, Irving AJ, Seal AJ, Henley JM, Jane DE, Watkins JC, Collingridge GL (1993) Induction of LTP in the hippocampus needs synaptic activation of glutamate metabotropic receptors. Nature 363:347-350.

Beal MF, Finn SF, Brouillet E (1993) Evidence for the involvement of metabotropic glutamate receptors in striatal excitotoxin lesions in vivo. Neurodegeneration 2:81-91.

Beckstead RM (1979) An autoradiographic examination of corticocortical and subcortical projections of the mediodorsal-projection (prefrontal) cortex in the rat. J Comp Neurol 184:43-62.

Bergman H, Wichmann T, DeLong M (1990) Reversal of experimental parkinsonism by lesions of the subthalamic nucleus. Science 249 . 1436-1438.

Biziere K, Coyle JT (1978) Influence of cortical-striatal afferents on striatal kainic acid neurotoxicity. Neurosci Lett 8:303-382.

Biziere K, Coyle JT (1979) Effects of cortical ablation on the neurotoxicity and receptor binding of kainic acid in the striatum. J Neurosci Res 4:383-398.

Bliss TVP, Collingridge GL (1993) A synaptic model of memory: longterm potentiation in the hippocampus. Nature 361:31-39.

Boss V, Conn PJ (1992) Metabotropic excitatory amino acid receptor activation stimulates phospholipase D in hippocampal slices. J Neurochem 59:2340-2343.

Brotchie JM, Crossman AR (1991) D- $\left[{ }^{3} \mathrm{H}\right]$ aspartate and $\left[{ }^{14} \mathrm{C}\right] \mathrm{GABA}$ uptake in the basal ganglia of rats following lesions in the subthalamic region suggest a role for excitatory amino acid but not GABA-mediated transmission in subthalamic nuclcus cfferents. Exp Neurol 113: 171-181.

Calabresi P, Maj R, Pisani A, Mercuri NB, Bernardi G (1992a) Longterm synaptic depression in the striatum: physiological and pharmacological characterization. J Neurosci 12:4224-4233.

Calabresi P, Mercuri NB, Bernardi G (1992b) Activation of quisqualate metabotropic receptors reduces glutamate and GABA-mediated synaptic potentials in the rat striatum. Neurosci Lett 139:4144.

Canteras NS, Shammah-Lagnado SJ, Silva BA, Ricardo JA (1990) Afferent connections of the subthalamic nucleus: a combined retrograde and anterograde horseradish peroxidase study in the rat. Brain Res 513:43-59.

Catania MV, Hollingsworth Z, Penney JB, Young AB (1993) Quisqualate resolves two distinct metabotropic ['H]glutamate binding sites. Neuroreport 4:311-313.

Cha JH, Makowiec RL, Penney JB, Young AB (1990) L- $\left[{ }^{3} \mathrm{H}\right]$ Glutamate labels the metabotropic excitatory amino acid receptor in rodent brain. Neurosci Lett 113:78-83.

Chéramy A, Romo R, Godeheu G, Baruch P, Glowinski J (1986) In vivo presynaptic control of dopamine release in the cat caudate nucleus. II. Facilitatory or inhibitory influence of $\mathbf{L}$-glutamate. Neuroscience 19:1081-1090.

Choi DW, Rothman SM (1990) The role of glutamate neurotoxicity in hypoxic-ischemic neuronal death. Annu Rev Neurosci 13:171182

Condorelli DF, Dell'Albani P, Amico C, Casabona G, Genazzani AA, Sortino MA, Nicoletti F (1992) Developmental profile of metabotropic glutamate receptor $\mathrm{mRNA}$ in rat brain. Mol Pharmacol 41: 660-664.

Fotuhi M, Sharp AH, Glatt CE, Hwang PM, von Krosigk M, Snyder SH, Dawson TM (1993) Differential localization of phosphoinositide-linked metabotropic glutamate receptor (mGluR1) and the ino- 
sitol 1,4,5-trisphosphate receptor in rat brain. J Neurosci 13:20012012.

Gerfen CR (1992) The neostriatal mosaic: multiple levels of compartmental organization. Trends Neurosci 15:133-139.

Giorguieff MF, Kemel ML, Glowinski J (1977) Presynaptic effects of L-glutamic acid on the release of dopamine in rat striatal slices. Neurosci Lett 6:73-77.

Graybiel AM (1990) Neurotransmitters and neuromodulators in the basal ganglia. Trends Neurosci 13:244-253.

Greenamyre JT, O'Brien CF (1991) $N$-methyl-D-aspartate antagonists in the treatment of Parkinson's disease. Arch Neurol 48:977-980.

Greenamyre JT, Higgins DS, Young AB, Penney JR (1990) Regional ontogeny of a unique glutamate recognition site in rat brain: an autoradiographic study. Int J Dev Neurosci 8:437-445.

Groencwegen HJ, Berendse HW (1990) Connections of the subthalamic nucleus with ventral striatopallidal parts of the basal ganglia in the rat. J Comp Neurol 294:607-622.

Hayashi Y, Tanabe Y, Aramori I, Masu M, Keiko S, Ohfune Y, Nakanishi S (1992) Agonist analysis of 2-(carboxycyclopropyl)glycine isomers for cloned metabotropic glutamate receptor subtypes expressed in Chinese hamster ovary cells. Br J Pharmacol 107:539-543.

Houamed KM, Kuijper JL, Gilbert TL, Haldeman BA, O'Hara PJ, Mulvihill ER, Almers W, Hagen FS (1991) Cloning, expression, and gene structure of a $G$ protein-coupled glutamate receptor from rat brain. Science 252:1318-1321.

Ishida M, Akagi H, Shimamoto K, Ohfune Y, Shinozaki H (1990) A potent metabotropic glutamate receptor agonist: electrophysiological actions of a conformationally restricted glutamate analogue in the rat spinal cord and Xenopus oocytes. Brain Res 537:311-314.

Ito M, Sakurai M, Tongroach P (1982) Climbing fibre induced depression of both mossy fiber responsiveness and glutamate sensitivity of cerebellar Purkinje cells. J Physiol (Lond) 324:113-134.

Kano M, Kato M (1987) Quisqualate receptors are specifically involved in cerebellar synaptic plasticity. Nature 325:276-279.

Kim JS, Hassler R, Haug P, Paik KS (1977) Effect of frontal cortex ablation on striatal glutamic acid level in the rat. Brain Res 132:370374

Kita H, Kitai ST (1987) Efferent projections of the subthalamic nucleus in the rat: light and electron microscopic analysis with the PHA-L method. J Comp Neurol 260:435-452.

Klockgether T, Turski L (1989) Excitatory amino acids and the basal ganglia: implications for the therapy of Parkinson's disease. Trends Neurosci 12:285-286.

Koh J-Y, Palmer E, Cotman CW (1991a) Activation of the metabotropic glutamate receptor attenuates $N$-methyl-D-aspartate neurotoxicity in cortical cultures. Proc Natl Acad Sci USA 88:9431-9435.

Koh J-Y, Palmer E, Lin A, Cotman CW (1991b) A metabotropic glutamate receptor agonist does not mediate neuronal degeneration in cortical culture. Brain Res 561:338-343.

Lee HJ, Rye DB, Hallanger AE, Levey AI, Wainer BH (1988) Cholinergic vs. noncholinergic efferents from the mesopontine tegmentum to the extrapyramidal motor system nuclei. J Comp Neurol 275:469492.

Lewis ME, Baldino F (1990) Probes for in situ hybridization histochemistry. In: In situ hybridization histochemistry, pp 1-21. Boston: CRC.

Linden DJ, Dickinson MH, Smeyne M, Connor JA (1991) A longterm depression of AMPA currents in cultured cerebellar Purkinje neurons. Neuron 7:81-89.

Manzoni O, Fagni L, Pin JP, Rassendren F, Poulat F, Sladeczek F, Bockaert J (1990) (Trans)-1-amino-cyclopentyl-1,3-dicarboxylate stimulates quisqualate phosphoinositide-coupled reccptors but not ionotropic glutamate receptors in striatal neurons and Xenopus oocytes. Mol Pharmacol 38:1-6.

Martin LJ, Blackstone CD, Huganir RL, Price DL (1992) Cellular localization of a metabotropic glutamate receptor in rat brain. Neuron 9:259-270.

Masu M, Tanabe Y, Tsuchida K, Shigemoto R, Nakanishi S (1991) Sequence and expression of a metabotropic glutamate receptor. $\mathrm{Na}$ ture 349:760-765

McDonald JW, Schoepp DD (1992) The metabotropic excitatory amino acid receptor agonist $1 S, 3 R-\mathrm{ACPD}$ selectively potentiates $N$-methyl-D-aspartate-induced brain injury. Eur J Pharmacol 215: 353-354.
McGeer PL, McGeer EG, Scherer U, Singh K (1977) A glutamatergic corticostriatal path? Brain Res 128:369-373.

Miller JA (1991) The calibration of ${ }^{35} \mathrm{~S}$ or ${ }^{32} \mathrm{P}$ with ${ }^{14} \mathrm{C}$-labeled brain pastc or ${ }^{14} \mathrm{C}$-plastic standards for quantitative autoradiography using LKB Ultrafilm or Amersham Hyperfilm. Neurosci Lett 121:211-214.

Moriyoshi K, Masu M, Ishii T, Shigemoto R, Mizuno N, Nakanishi S (1991) Molecular cloning and characterization of the rat NMDA receptor. Nature 354:31-37.

Nakanishi H, Kita H, Kitai ST (1987) Intracellular study of rat substantia nigra pars reticulata neurons in an in vitro slice preparation: electrical membrane properties and response characteristics to subthalamic stimulation. Brain Res 437:45-55.

Nakanishi S (1992) Molecular diversity of glutamate receptors and implications for brain function. Science 258:597-603.

Ohfune Y, Shimamoto K, Ishida M, Shinozaki H (1993) Synthesis of L-2-(2,3-dicarboxycyclopropyl)glycines. Novel conformationally restricted glutamate analogues. Bioorg Med Chem Lett 3:15-18.

Ohishi H, Shigemoto R, Nakanishi S, Mizuno N (1993) Distribution of the messenger RNA for a metabotropic glutamate receptor, mGluR2, in the central nervous system of the rat. Neuroscience 53:1009-1018.

Paskevich PA, Evans HK, Domesick VB (1991) Morphological assessment of neuronal aggregates in the striatum of the rat. J Comp Neurol 305:361-369.

Phelps PE, Vaughn JE (1986) Immunocytochemical localization of choline acetyltransferase in rat ventral striatum: a light and electron microscopic study. J Neurocytol 15:595-617.

Phelps PE, Houser CR, Vaughn JE (1985) Immunocytochemical localization of choline acetyltransferase within the rat neostriatum: a correlated light and electron microscopic study of cholinergic neurons and synapses. J Comp Neurol 238:286-307.

Pin JP, Waeber C, Prezeau L, Bockaert J, Heinemann SF (1992) Alternative splicing generates metabotropic glutamate receptors inducing different patterns of calcium release in Xenopus oocytes. Proc Natl Acad Sci USA 89:10331-10335.

Price RH, Hollingsworth Z, Young AB, Penney JB (1993) Excitatory amino acid receptor regulation after subthalamic nucleus lesions in the rat. Brain Res 602:157-160.

Robledo P, Feger J (1990) Excitatory influence of rat subthalamic nucleus to substantia nigra pars reticulata and the pallidal complex: electrophysiological data. Brain Res 518:47-54.

Sacaan AI, Schoepp DD (1992) Activation of hippocampal metabotropic excitatory amino acid receptors leads to seizures and neuronal damage. Neurosci Lett 139:77-82.

Sacaan AI, Monn JA, Schoepp DD (1991) Intrastriatal injection of a selective metabotropic excitatory amino acid receptor agonist induces contralateral turning in the rat. J Pharmacol Exp Ther 259:13661370.

Sacaan AI, Bymaster FP, Schocpp DD (1992) Mctabotropic glutamate receptor activation produces extrapyramidal motor system activation that is mediated by dopamine. J Neurochem 59:245-251.

Saugstad JA, Segerson TP, Mulvihill ER, Westbrook GL (1992) Isolation of novel metabotropic glutamate receptor cDNAs from rat olfactory bulb. Soc Neurosci Abstr 18:1363.

Schoepp DD, Conn PJ (1993) Metabotropic glutamate receptors in brain function and pathology. Trends Pharmacol Sci 14:13-20.

Schoepp D, Bockaert J, Sladeczek F (1990) Pharmacological and functional characteristics of metabotropic excitatory amino acid receptors. Trends Pharmacol Sci 11:508-515.

Schoepp DD, Johnson BG, Salhoff CR, McDonald JW, Johnston MV (1991) In vitro and in vivo pharmacology of trans- and cis-( \pm )-1amino-1,3-cyclopentanedicarboxylic acid: dissociation of metabotropic and ionotropic excitatory amino acid receptor effects. J Neurochem 56:1789-1796.

Schoepp DD, Johnson BG, Monn JA (1992) Inhibition of cyclic AMP formation by a selective metabotropic glutamate receptor agonist. $J$ Neurochem 58:1184-1186.

Shigemoto R, Nakanishi S, Mizuno N (1992) Distribution of the mRNA for a metabotropic glutamate receptor (mGluR 1 ) in the central nervous system: an in situ hybridization study in adult and developing rat. J Comp Neurol 322:121-135.

Sladeczak F, Pin J-P, Récasens M, Bockaert J, Weiss S (1985) Glutamate stimulates inositol phosphate formation in striatal neurons. Nature 317:717-719.

Sladeczek F, Recasens M, Bockaert J (1988) A new mechanism for 
glutamate receptor action: phosphoinositide hydrolysis. Trends Neurosci 11:545-549.

Smith Y, Parent A (1988) Neurons of the subthalamic nucleus in primates display glutamate but not GABA immunoreactivity. Brain Res 453:353-356.

Sokoloff P, Giros B, Martres M-P, Bouthenet M-L, Schwartz J-C (1990) Molecular cloning and characterization of a novel dopamine receptor (D3) as a target for neuroleptics. Nature 347:146-151.

Standaert DG, Testa CM, Penney JB, Young AB (1993a) Alternatively spliced isoforms of the NMDARI glutamate receptor: differentia expression in the basal ganglia of the rat. Neurosci Lett 152:161-164.

Standaert DG, Testa CM, Young AB, Penney JB (1994) Organization of $N$-methyl-D-aspartate (NMDA) glutamate receptor gene expression in the basal ganglia of the rat. J Comp Neurol, in press.

Tanabe Y, Masu M, Ishii T, Shigemoto R, Nakanishi S (1992) A family of metabotropic glutamate receptors. Neuron 8:169-179.
Tanabe Y, Nomura A, Masu M, Shigemoto R, Mizuno N, Nakanishi S (1993) Signal transduction, pharmacologic properties, and expression patterns of two rat metabotropic glutamate receptors, mGluR3 and mGluR4. J Ncurosci 13:1372-1378.

Winder DG, Conn PJ (1992) Activation of metabotropic glutamate receptors in the hippocampus increases cyclic AMP accumulation. J Neurochem 59:375-378.

Winder DG, Conn PJ (1993) Activation of metabotropic glutamate receptors increases cAMP accumulation in hippocampus by potentiating responses to endogenous adenosine. J Neurosci 13:38-44.

Young AB, Bromberg MB, Penney JB (1981) Decreased glutamate uptake in subcortical areas deafferented by sensorimotor cortical ablation in the cat. J Neurosci 1:241-249.

Young WS III, Kuhar MJ (1986) Quantitative in situ hybridization and determination of mRNA content. In: In situ hybridization in brain, pp 243-248. New York: Plenum. 